\title{
Retaining Women in Collegiate Aviation by Implementing Learning Style Considerations
}

\author{
Merrill R. Karp, Mary Ann Turney, Mary Niemczyk \\ Arizona State University
}

Mavis F. Green

Embry-Riddle Aeronautical

University

Ruth L. Sitler

Kent State University

James Bishop

Bryant College

\begin{abstract}
Women are clearly underrepresented in aviation. Research must be accomplished to determine which factors influence women, once they have indicated a serious interest in an aviation career, to stay in collegiate aviation programs or to leave. Addressing the issue of women's retention in aviation is one way to help address the growing commercial pilot shortage, while moving toward gender equity in this critical, national industry. Projected shortages in the commercial pilot population, coupled with the low representation of women in career pilot positions, suggest that aviation education and training institutions should re-examine the structure and organization of the aviation knowledge transfer process. Classroom enhancements could improve education methods to make them more efficient from the perspectives of increased knowledge retention, improved application to broader subjects, and reduced loss to attrition of viable pilot candidates to enter the commercial pilot workforce. This study examines how aviation education can best serve the aviation student's learning style needs. The study looks at learning style theory, from the viewpoint of the wide diversity of aviation learners who are dominantly visual, auditory, or hands-on, tactile, or kinesthetic learners, and how women's learning styles are pivotal to their success and retention in collegiate aviation. By exploring how people learn best, and then providing those learners with the tools to maximize their dominant learning styles, the next generation of pilots, both women and men, should be better prepared to enter the aviation industry and help reduce the projected commercial pilot shortages.
\end{abstract}

\section{BACKGROUND}

The number of working women has tripled since the mid-1940's (Naisbitt \& Aburdene, 1990). Yet women continue to remain underrepresented in the aviation field. Despite governmental and industry policies which encourage women to join the aviation industry, women constitute less than $6 \%$ of all FAA licensed pilots. The small number of women entering careers in aviation is evidenced in collegiate aviation where enrollment and retention of women remain low (Turney, Karp, Green, \& Sitler, 1999). Recent studies indicate that women are underrepresented in aerospace 
engineering, as well as aviation in general (Bowen \& Mathis, 1991).

In parallel with the low number of women in aviation, there is a critical shortage of commercial airline pilots. A congressional-directed United States Department of Transportation Federal Advisory Committee study in 1993 projected a shortage of qualified airline pilots that could impact the future availability of commercial air transportation in the United States. This study indicated that expansion of airline capacity, in combination with retirements from the airline pilot force and a reduced pool of former military pilots, would result in a national shortage of qualified pilots through 2010, and beyond, unless positive actions were taken (United States Department of Transportation Federal Advisory Committee, 1993, pp. vii-xxiii, Appendix D, Table 1 and Table 4).

While extensive research has been conducted to improve aviation flight training and simulation (Green, 1998), little has been done to improve the classroom component of aviation education (Karp, 1996). The pertinent commercial pilot supply issue to consider is that of the depth and quality of aviation academic education, as well as the flight training, of those future airline pilots. Because of the increasing sophistication of modern aircraft and high technology equipment, this topic underscores a need to examine, and restructure where necessary, the training options for potential airline pilots. Any academic program must ensure that the aviation education process involves an in-depth, effective transfer of knowledge across a broad spectrum of aviation subjects. When considering aviation education, the academic component of the flight training plays an important role in providing the knowledge base for a new pilot. This academic education has the potential to build an exceptionally solid foundation for ensuring the high standard of technical and flying knowledge needed for future airline pilots.

Gender also plays an important role in learning success in the aviation classroom or on the flight line. Research has shown that women do not learn the same as men (Turney, 1995). For example, while men often prefer debate-like situations in which they pursue knowledge, women most frequently like to share and learn by interacting with each other (Tannen, 1990). Additionally, females often are very participatory in their learning styles, while men tend to be more independent (Emanuel \& Potter, 1992). Women also need to master an entire concept before moving on to new information. They require a "big picture" approach to learning (Stuart, 1999). Aviation curriculum development and delivery should take into consideration those learning styles that are unique to both men and women, in order to maximize their retention, and success, in the aviation career field.

In developing educational programs, it is important to know how people learn the best, and why they succeed. Because of the depth and complexity of the subject matter, aviation academic instructors must present the course material in ways that satisfy the different needs and styles of the aviation learners. Likewise, each student must understand her or his learning style and maintain more focused attention to the information when it is being presented in a teaching style that is not easily compatible with their learning style.

This paper on dominant learning styles is part of a larger research effort by the authors on "Maximizing retention of women students enrolled in collegiate aviation programs." This overall research is funded by grants from the Department of Education, Fund for Improvement of PostSecondary Education (FIPSE) and the 
Alfred P. Sloan Foundation. In this larger, three-year study, the researchers are currently collecting data to determine what factors influence the retention of women in collegiate aviation programs. The research is focused on determining factors that influence the decisions of women to either complete or drop out of aviation programs, and then to identify potential modifications to aviation education in the collegiate setting that could improve the retention of women aviation students and enhance their preparation for careers in commercial air transportation.

\section{LEARNING STYLE RESEARCH}

The implementation of learning style considerations in aviation education should play an important role in this model to improve the retention of women in aviation.

\section{Learning Style Theory}

Learning style theory, that is, the way people learn best, is of considerable importance in developing and delivering aviation academic programs. One model suggests that there are three recognized primary, or dominant, learning styles: First, visual learners, who learn best by reading or looking at pictures. Second, auditory, or aural, learners, who learn best by listening. And third, hands-on, tactile, or kinesthetic learners, who need to use their hands or whole body to learn (Filipczak, 1995). If knowledge transfer is to take place within the entire classroom population, then all of these dominant learning styles should be addressed in the academic environment.

In this study, a learning style assessment instrument (Appendix A) was administered to 390 collegiate aviation students (195 women and 195 men) from representative aviation students of university and college members of the University Aviation Association (UAA) from around the country. This instrument was part of the larger research administered for the overall effort of "Maximizing retention of women students enrolled in collegiate aviation programs." The individual university and college aviation faculty representatives who assisted in the data collection distributed the surveys to all of their female aviation students and an equal number of their male aviation students.

\section{Results of Learning Style Research Women Respondents \\ Of the 195 women respondents, 112} $(57.4 \%)$ were either dominant hands-on learners, or an equal combination of handson and visual and/or auditory learners (Table 1).

\begin{tabular}{|l|l|l|}
\hline Learning Style & Number & Percentage \\
\hline $\begin{array}{l}\text { Visual } \\
\text { (dominant) }\end{array}$ & 62 & $31.8 \%$ \\
\hline $\begin{array}{l}\text { Auditory } \\
\text { (dominant) }\end{array}$ & 15 & $7.7 \%$ \\
\hline $\begin{array}{l}\text { Hands-On } \\
\text { (dominant) }\end{array}$ & 87 & $44.6 \%$ \\
\hline $\begin{array}{l}\text { Visual/Auditory } \\
\text { (equal dominance) }\end{array}$ & 6 & $3.1 \%$ \\
\hline $\begin{array}{l}\text { Auditory/Hands-On } \\
\text { (equal dominance) }\end{array}$ & 7 & $3.6 \%$ \\
\hline $\begin{array}{l}\text { Visual/Hands-On } \\
\text { (equal dominance) }\end{array}$ & 15 & $7.7 \%$ \\
\hline $\begin{array}{l}\text { Visual/Auditory/ } \\
\text { Hands-On (equal) }\end{array}$ & 3 & $100 \%$ \\
\hline Total & 195 & \\
\hline
\end{tabular}

Table 1. Dominate learning styles of women respondents $(\mathrm{n}=195)$

\section{Men Respondents}

Of the 195 men respondents, 118 (60.5\%) were either dominant hands-on learners, or an equal combination of hands-on and visual and/or auditory learners (Table 2).

Comparison of Women and Men Respondents

Comparing the results of the women and men respondents, a picture becomes 
apparent that women and men in collegiate aviation are very similar in their dominant learning styles. For example, $44.6 \%$ of the women indicated that they were dominantly hands-on learners, compared to $45.1 \%$ of the men respondents.

\begin{tabular}{|l|l|l|}
\hline Learning Style & Number & Percentage \\
\hline $\begin{array}{l}\text { Visual } \\
\text { (dominant) }\end{array}$ & $\mathbf{5 6}$ & $\mathbf{2 8 . 7 \%}$ \\
\hline $\begin{array}{l}\text { Auditory } \\
\text { (dominant) }\end{array}$ & $\mathbf{1 5}$ & $\mathbf{7 . 7 \%}$ \\
\hline $\begin{array}{l}\text { Hands-On } \\
\text { (dominant) }\end{array}$ & $\mathbf{8 8}$ & $\mathbf{4 5 . 1 \%}$ \\
\hline $\begin{array}{l}\text { Visual/Auditory } \\
\text { (equal dominance) }\end{array}$ & $\mathbf{6}$ & $\mathbf{3 . 1 \%}$ \\
\hline $\begin{array}{l}\text { Auditory/Hands-On } \\
\text { (equal dominance) }\end{array}$ & $\mathbf{1 0}$ & $\mathbf{5 . 1 \%}$ \\
\hline $\begin{array}{l}\text { Visual/Hands-On } \\
\text { (equal dominance) }\end{array}$ & $\mathbf{1 4}$ & $\mathbf{7 . 2 \%}$ \\
\hline $\begin{array}{l}\text { Visual/Auditory/ } \\
\text { Hands-On (equal) }\end{array}$ & $\mathbf{6}$ & $\mathbf{3 . 1 \%}$ \\
\hline Total & $\mathbf{1 9 5}$ & $\mathbf{1 0 0 \%}$ \\
\hline
\end{tabular}

Table 2. Dominate learning styles of men respondents $(n=195)$

A quantitative analysis was performed comparing male and female learning styles (without consideration of equal dominance). For this analysis, each respondent was considered to have a percentage of responses in each of the three categories. Percentages were used because males tended to give more responses than females and so accurate analysis required the use of proportions.

A two-sided unpaired t-test was used to compare the male and female responses for each of the three learning styles. The resulting $p$-values for the visual and handson responses showed no significant result at any reasonable significance level. The responses in these two categories were clearly very close. The auditory p-value was .18 , which does not show significance at a reasonable level (.05 or .10). However, this does suggest the possibility that males are slightly less auditory than females.
Composite of Women and Men Respondents Of the total of 390 women and men respondents, $221 \quad(56.7 \%)$ were either dominant hands-on learners, or an equal combination of hands-on and visual and/or auditory learners (Table 3 ).

\begin{tabular}{|l|l|c|}
\hline Learning Style & Number & Percentage \\
\hline $\begin{array}{l}\text { Visual } \\
\text { (dominant) }\end{array}$ & $\mathbf{1 1 8}$ & $\mathbf{3 0 . 3 \%}$ \\
\hline $\begin{array}{l}\text { Auditory } \\
\text { (dominant) }\end{array}$ & $\mathbf{3 0}$ & $\mathbf{7 . 7 \%}$ \\
\hline $\begin{array}{l}\text { Hands-On } \\
\text { (dominant) }\end{array}$ & $\mathbf{1 7 5}$ & $\mathbf{4 4 . 9 \%}$ \\
\hline $\begin{array}{l}\text { Visual/Auditory } \\
\text { (equal dominance) }\end{array}$ & $\mathbf{1 2}$ & $\mathbf{3 . 1 \%}$ \\
\hline $\begin{array}{l}\text { Auditory/Hands-On } \\
\text { (equal dominance) }\end{array}$ & $\mathbf{1 7}$ & $\mathbf{4 . 3 \%}$ \\
\hline $\begin{array}{l}\text { Visual/Hands-On } \\
\text { (equal dominance) }\end{array}$ & $\mathbf{2 9}$ & $\mathbf{7 . 4 \% \%}$ \\
\hline $\begin{array}{l}\text { Visual/Auditory/ } \\
\text { Hands-On (equal) }\end{array}$ & $\mathbf{9} \%$ \\
\hline Total & $\mathbf{3 9 0}$ & $\mathbf{1 0 0 \%}$ \\
\hline
\end{tabular}

Table 3. Dominant learning styles of both women and men respondents $(n=390)$

Comparison of Women and Men Respondents to a Previous Study

A combination of the women and men together (Table 3) can be used to compare this study's findings with a previous study to validate the consistency of the results. In an earlier study (Karp, 2000), when examining the learning style assessments over a two-year period of a composite of 117 respondents, from private pilots to F-16 pilots, the research (Table 4) indicated that $58.1 \%$ of the pilots were either dominantly hands-on learners, or an equal combination of hands-on and visual and/or auditory learners. When comparing this $58.1 \%(n=117)$ to the combined women and men results of $58.9 \%$ of this current study $(n=390)$, or the women only results of $57.4 \% \quad(n=195)$, a parallel propensity surfaces: Individuals in collegiate aviation, whether they are women or men, are very 
dominantly hands-on learners and need that "tactile" connection to process and retain knowledge.

\begin{tabular}{|l|l|l|}
\hline Learning Style & Number & Percentage \\
\hline $\begin{array}{l}\text { Visual } \\
\text { (dominant) }\end{array}$ & $\mathbf{3 8}$ & $\mathbf{3 2 . 5 \%}$ \\
\hline $\begin{array}{l}\text { Auditory } \\
\text { (dominant) }\end{array}$ & $\mathbf{8}$ & $\mathbf{6 . 8 \%}$ \\
\hline $\begin{array}{l}\text { Hands-On } \\
\text { (dominant) }\end{array}$ & $\mathbf{5 2}$ & $\mathbf{4 4 . 4 \%}$ \\
\hline $\begin{array}{l}\text { Visual/Auditory } \\
\text { (equal dominance) }\end{array}$ & $\mathbf{3}$ & $\mathbf{2 . 6 \%}$ \\
\hline $\begin{array}{l}\text { Auditory/Hands-On } \\
\text { (equal dominance) }\end{array}$ & $\mathbf{0}$ & $\mathbf{0}$ \\
\hline $\begin{array}{l}\text { Visual/Hands-On } \\
\text { (equal dominance) }\end{array}$ & $\mathbf{1 6}$ & $\mathbf{1 3 . 7 \%}$ \\
\hline $\begin{array}{l}\text { Visual/Auditory/ } \\
\text { Hands-On (equal) }\end{array}$ & $\mathbf{0}$ & $\mathbf{0}$ \\
\hline Total & $\mathbf{1 1 7}$ & $\mathbf{1 0 0 \%}$ \\
\hline
\end{tabular}

Table 4 Dominant learning styles of both women and men respondents in previous study $(\mathrm{n}=117)$

\section{Evaluation of Results}

In spite of this majority of pilots being predominantly either hands-on or an equal combination of hands-on and visual and/or auditory learners, research indicates that most classroom environments are auditory in nature, with visual supplementation, and very little, if any, hands-on learning applications (Karp, 2000).

\section{Computer-Based Training}

A valuable tool to assist in hands-on learning, in connection with the classroom, is computer-based training, to include the use of PC-based flight simulator programs. With the increased access to computer-based tutoring programs, students are moving away from passive reception of information to more active engagement in the acquisition of knowledge (Kozma \& Johnston, 1991). Computer programs for tutoring technical subjects can be particularly useful in aviation education. Computer-Based Training (CBT) programs can be used extensively for pre-class preparation, as well as post-class review and immediate reinforcement. CBT programs allow the student to accomplish self-paced learning in a non-threatening environment. In addition to supporting the CBT programs, the same basic computer equipment can be augmented with a control yoke and throttles to be used with personal computer-based flight simulator programs. These personal computer-based flight simulator programs are relatively low-cost training vehicles that can be easily and effectively integrated into an aviation education curriculum. They are well suited as an educational bridge between the basic, traditional aviation classroom and the advanced, high technology aviation flight environment (Karp, 1996). However, the key is that personal computer-based training with interactive flight simulator programs helps provide the educational components in multiple learning styles, thereby meeting more individuals' learning needs than are provided by classroom lecture alone.

Sitler (1998) identified a series of things instructor pilots should know about women so that they can support retention of women pilots. Some of her many examples underscore issues highlighted in this study on learning styles. While Sitler's research indicated that women appear to be slower than men to grasp some subjects, such as aerodynamics, women are alternatively quicker than men to grasp instrument flight and once they learn an established procedure, they rarely vary it. In this example, by using computer based training and PC-based simulator programs in connection with the classroom environment to be able to "visualize" the effects of aerodynamic factors while making control inputs on a PC-based flight simulator, women's strengths of quickly learning to fly instruments and using set procedures could be used to overcome initial knowledge 
transfer difficulties through this immediate hands-on application vehicle.

\section{RECOMMENDATIONS}

1. Educators should administer to all aviation students a "quick and easy-to-take" learning style assessment instrument (similar to Appendix A), to help them identify, for themselves, their own dominant learning style. The educator should then facilitate a discussion with the learners on how they might maximize their dominant learning style in day-to-day learning situations (by using an aid similar to Appendix B). A side finding of the earlier research of the 117 aviation students from a wide range of pilots was that most respondents thought that everyone learned about the same and were surprised at the differences among their classmates. Similarly, the same observation was made for instructors; many instructors taught in the style that they, themselves, learned best, without thinking about potential differences for their students.

2. Educators should present their aviation curriculum using all three learning style environments (visual, auditory, and hands-on) so that all students have the best opportunity to reinforce the material using their dominant learning style(s). Employing PC-based training, including PC-based flight simulator programs, immediately following the classroom experience, is an excellent reinforcing vehicle to provide the hands-on learning opportunities that are critically needed by a large number of both women and men aviation students.

\section{CONCLUSION}

This paper addresses aviation educational enhancements through the implementation of learning style theory, including gender specific differences and the inclusion of personal computer-based flight simulator programs, to help retain more women in aviation programs by providing a "comfortable, reinforcing" learning environment that aligns with their own learning style. The emphasis on the use of PC-based flight simulator programs is not aimed at reducing flight training or corresponding simulator training, but is rather focused on providing immediate, hands-on application following each academic class. Providing immediate, hands-on application is directed toward on improving understanding and long-term retention of the subject matter, as well as increasing knowledge application across a broader spectrum. By presenting the classroom academic components so as to also accommodate hands-on learners, in addition to the historical presentation of the material in visual and auditory formats, more students (both male and female) should be able to maximize their learning potential because their specific learning needs will be addressed. For individuals who are not learning the subject matter fast enough because their learning style needs are not being met, presenting the material in visual, auditory, and hands-on formats should lead to increased student retention in aviation, if all other factors remain constant.

The retention of women in aviation programs is a particularly important factor to consider in meeting future commercial pilot requirements. While women constitute only a small percentage of the commercial pilot force, they comprise a large resource pool from which the commercial aviation industry can draw. In order to retain the best people in aviation programs, aviation academic providers must design their academic curriculum and delivery vehicles to meet their students' specific learning styles, whether they are women or men. The investment in time for curriculum development to include all learning styles in an integrated aviation education program 
should pay high dividends in expanding the aviation learners' knowledge base and enhancing their flexibility to address new situations, while increasing the retention of women in collegiate aviation programs. 


\section{REFERENCES}

Bowen, B. \& Mathis, J. (1991, September). Women in aerospace engineering faculty of higher education. Frontiers in Education. American Society of Engineering Education. Purdue University.

Emanuel, R. \& Potter, W. (1992). Do Students' style preferences differ by grade level, orientation toward college, and academic major? Research in Higher Education, 33, 395-414.

Filipczak, B. (1995, March). Different strokes: Learning in the classroom. Training, 32, 43-48.

Green, M.F. (1998). Aviation instruction through flight simulation and related learning. Doctoral Dissertation. University of Illinois, Urbana-Champaign.

Karp, M.R. (2000, October). University Aviation Education: An integrated model. Collegiate Aviation Review, 18, (1).

Karp, M. (1996). Theoretical aviation training for future airline pilots. Doctoral Dissertation, Walden University, Minneapolis, MN. UMI 9713644.

Kozma, R. \& Johnston, J. (1991, January). The technological revolution comes to the classroom. Change, 16-18.

Naisbitt, J. \& Aburdene, P. (1990). Megatrends 2000. NY: William Morrow Co.

Sitler, R. L. (1998). The cockpit classroom: Women's perceptions of learning to fly and implications for flight curriculum and instruction. A dissertation submitted to Kent State University, Kent, Ohio.

Stuart, R. (1999). Gender differences in the cockpit. New Zealand Wings Magazine.

Tannen, D. (1990). You just don't understand: Women and men in conversation. New York: Ballentine Books.

Turney, M. (1995). Women's learning and leadership styles: Impact on CRM. Proceedings of the 21st Conference of the European Association for Aviation Psychology, Volume 1, Applications of Psychology to the Aviation System. Brookfield, Vermont: Ashgate Publishing Company.

Turney, M, Karp, M., Green, M. \& Sitler, R. (1999). Report: Maximizing retention of women Students Enrolled in Collegiate Aviation Programs. New York City, NY: Alfred P. Sloan Foundation.

United States Department of Transportation Federal Advisory Committee (1993, August). Pilots and aviation maintenance technicians for the twenty-first century: Assessment of availability and quality. Washington D.C.: U.S. Government Printing Office. 


\section{Appendix A}

\section{PERSONAL CHARACTERISTICS}

Directions: Circle the phrases that you think best reflect your personal characteristics. Circle as many phrases as you feel are applicable.

Observe rather than talks or acts

Organized in approach to tasks

Like to read

Usually a good speller

Memorize by seeing pictures or graphics

Not easily distracted

Find verbal instruction difficult

Have good handwriting

Remember faces

Use advanced planning

Doodle

Quiet by nature

Meticulous, neat in appearance

Notice details
Talk to myself aloud

Enjoy talking to others

Easily distracted

Have more difficulty with written directions

Like to be read to

Memorize steps in a sequence

Enjoy music

Whisper to myself while reading

Remember names

Easily distracted by noises

Hum or sing

Outgoing by nature

Enjoy listening activities

Enjoy programs where a speaker tells stories
In motion most of the time

Like to touch people when talking to them

Like to handle objects

Tap pencil or foot while studying

Enjoy doing activities

Reading is not a priority

Usually a poor speller

Like to solve problems by physically working through them

Will try new things

Use hands when talking

Express emotions thorough physical means

Dress for comfort

Outgoing by nature

Like working with hands

Adapted by Dr. Merrill R. Karp, Arizona State University, from instrument by Jan R. Amstutz, Director, Intensive English Language Center, California State University, as presented to "Aviation Communication: A Multi-Cultural Forum Symposium,” April 11, 1997, Embry-Riddle Aeronautical University, Prescott, AZ. 


\section{APPENDIX B}

\section{Suggested Aids for Learning Styles}

Directions: Add each individual column of the "Personal Characteristics" assessment instrument. The first column indicates characteristics of "visual learners," the second column indicates characteristics of "auditory learners," and the third column reflects characteristics of "hands-on, tactile, or kinesthetic learners." The column with the highest number of annotated occurrences reflects the most dominant learning style; the column with the second most occurrences reflects the second most dominant learning style, etc. There is a possibility that two or even three of the columns are the same. If so, then those styles are equally dominant. The following aids may be helpful to enhance your particular dominant learning style, or to strengthen a weaker one. Some of the suggestions are the same for more than one learning style, but for different learning and processing reasons.

Visual
Form pictures in your mind
Take notes in class
Use notebooks to summarize
notes after class
Draw/use drawings
Use charts or graphs
Use maps
Watch lips move in front of
mirror while speaking
Use study cards
Use photographs and pictures
Watch TV
Watch videos
Use color codes
and acronyms, visual chains,
Mind maps

\section{$\underline{\text { Auditory }}$}

Use video and audiotapes

Watch TV

Speak/listen to speakers

Make up rhymes/poems

Read aloud

Talk to self

Repeat things orally

Use rhythmic sounds

Have discussions with

classmates

Listen carefully

Use oral directions

Sound out words

Say words in syllables

Use word links, like rhymes, poems, lyrics

\section{$\underline{\text { Hands-on/Kinesthetic }}$}

Physically "do" the task

Practice by repeated motion

Pace/walk as you study

Take a lot of notes in class

Write down thoughts during

day-to-day activities

Write on surface with finger

if paper is not available

Write lists repeatedly

Role-play

Think or practice while exercising

Associate feelings with concept/information

Stretch/move in chair

Watch lips move in front of mirror while going over lessons

Adapted by Dr. Merrill R. Karp, Arizona State University, from instrument by Jan R. Amstutz, Director, Intensive English Language Center, California State University, as presented to "Aviation Communication: A Multi-Cultural Forum Symposium,” April 11, 1997, Embry-Riddle Aeronautical University, Prescott, AZ. 